\title{
Injuries related to consumer products in Canada-a systematic literature review
}

\author{
S. A. Huchcroft, PhD (1); C. R. McGowan, PhD (2); F. Mo, PhD (3)
}

This article has been peer reviewed.

\section{Abstract}

Objectives: To conduct a systematic literature review of injury related to certain consumer products.

Methods: Forty-six empirical research reports along with 32 surveillance reports from the Canadian Hospitals Injury Reporting and Prevention Program (CHIRPP) were examined to determine the approximate number of injuries associated with a given product per year and any trends in frequency. Percentages of injuries that: (1) resulted in hospitalization, (2) appeared to result from the product itself and (3) were associated with risky or inappropriate use and/or non-use of a helmet were also extracted from the reports.

Results: Outdoor play and sports equipment appear to be associated with the greatest numbers of injuries. A relatively high proportion of injuries appear to result from inappropriate or risky use of a product and/or inadequate safety precautions.

Conclusion: This review identified the following areas of concern regarding consumer products and injuries: lack of helmet use by people using in-line skates, sleds, snowboards, downhill skis and personal-powered watercraft; operation of all-terrain vehicles (ATVs) and snowmobiles by alcohol-impaired people; operation of snowmobiles at excessive speeds; poor design of playground equipment; and unsafe storage and use of matches.

\section{Introduction}

(1) The quality of the product and its potential to cause injury by defects or characteristics such as sharp edges, faulty workmanship, poor assembly and product failure;

fied as an injury prevention priority in Canada. ${ }^{1}$ Data from the Canadian Hospitals Injury Reporting and Prevention Program (CHIRPP) ${ }^{2, *}$ indicate that almost half of injuries in children and youth (aged 19 years and less) are related to consumer products. ${ }^{3}$

(2) Factors related to how the product is used, for example, with too much force or speed, for an inappropriate purpose, or carelessly;

(3) The element of chance whereby a sound product is used appropriately but an accident that possibly could not have been predicted or prevented occurs; and products:
(4) Non-use of protective gear that could prevent or reduce the severity of injury in some instances.

This paper presents the results from a systematic review of the literature on the topic of injury related to consumer products in Canada. It examines, by product, what proportion of injuries may have resulted from a fault in the product itself or from inappropriate or risky use; what proportion of injured people were not using a helmet (where appropriate) when injured; the frequency and severity of injury by product; and any reported frequency trends.

\section{Methods}

Definitions of consumer product and injury

According to the Canada Consumer Product Safety Act (CCPSA), a consumer product is

“a product, including its components, parts or accessories, that may reasonably be expected to be obtained by an individual to be used for non-commercial purposes, including for domestic, recreational and sports purposes, and includes its packaging.,"4, section 2

Excluded from this definition are firearms, ammunition and explosives, cross-bows, food and drugs, pest control products, feeds, fertilizers, plants, seeds, controlled substances, aeronautical products, animals,

* CHIRPP is a computerized information system that collects and analyzes data on injuries to people seen at the emergency rooms of 10 pediatric and 4 general hospitals in Canada. More than $80 \%$ of the over 1.5 million records concern children and youth aged 19 years and younger. ${ }^{2}$ CHIRPP data are hospital-based and therefore only contain information about injuries in those who presented to hospital.

Author references:

1. Epidemiology Consultant, Calgary, Alberta, Canada

2. Department of Public Health and Policy, London School of Hygiene \& Tropical Medicine, London, United Kingdom

3. Science Integration Division, Centre for Chronic Disease Prevention and Control, Public Health Agency of Canada, Ottawa, Ontario, Canada

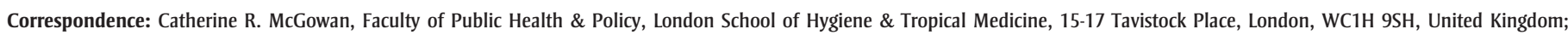
Tel.: (011 44) 207927 2888; Email: Catherine.McGowan@Ishtm.ac.uk 
tobacco and tobacco products, boats and vehicles within the meaning of section 2 of the Motor Vehicle Safety Act (MVSA) (i.e. "any vehicle that is capable of being driven or drawn on roads by any means other than muscular power exclusively....'). , section $2^{2}$ However, even though they technically fall under the MVSA, off-road recreational powered vehicles, such as all-terrain vehicles (ATVs), snowmobiles and powered scooters, have been included in this review. Injuries in team sports that use equipment, such as soccer, hockey or baseball, were excluded from this review because they are fairly discrete categories that merit separate reviews, as were injuries resulting from poisonings. Finally, we did include playground equipment because, although not strictly domestic, Health Canada includes it among consumer products. ${ }^{6}$

The definition of injury was problematic in that the CCPSA does not define it. However, in the context of this review, injury implies International Classification of Diseases, 10th Revision (ICD-10) ${ }^{7}$ External Cause of Injury codes for unintentional injuries V01-X59, Y85-Y86, excluding motor vehicle traffic injuries occurring on a public highway or street where the injured person is an occupant, poisonings, complications of medical and surgical care, self-inflicted injuries and injuries due to assault, undetermined intent and legal intervention/war. It includes injuries to the head, neck, thorax, abdomen, lower back, lumbar spine, pelvis, shoulder and upper arm, elbow and forearm, wrist and hand, hip and thigh, knee and lower leg, ankle and foot (ICD-10 site codes S00-S99), and multiple body regions, unspecified parts of trunk, limb or body region, effects of foreign body entering through natural orifice, burns and corrosions (ICD-10 codes T00-T32). Because the majority of articles did not define injury, nor cite ICD codes, this systematic literature review relies on the definition of injury as described by the authors of the included material. All injuries were attended by a medical professional, most often in a hospital emergency department.

\section{Systematic literature review search strategy}

We searched seven databases covering: allied health, clinical medicine, nursing and health policy (CINAHL Plus, EMBASE, MEDLINE); general science (Web of Science); public health (Global Health); social science (Social Policy \& Practice), and applied life sciences (CAB Abstracts). The search took place in February 2011 and included literature published over the last 20 years.

The search terms were: Canad* + (injur* or accident $\left.{ }^{*}\right)+$ (consumer* ${ }^{*}$ or product*). As a convenient crosscheck for the thoroughness of this search, we examined the much larger number of results from an earlier search for a separate project on risk factors related to injury, conducted in July 2010. The risk factor search terms were Canad* + (injur* or accident*) + (risk factor or inciden* or caus* or hospital* or mortality or disabilit* or fall*). This larger search did not identify any additional research on consumer-product-related injury.

We also considered various additional sources including books, book chapters, electronic articles and reports. Three important sources published by the Public Health Agency of Canada (PHAC) were Child and Youth Injury in Review, 2009 Edition -- Spotlight on Consumer Product Safety; ${ }^{3}$ CHIRPP Injury Reports/ Briefs/Data Samplers; ${ }^{8}$ and Inventory of Injury Data Sources and Surveillance Activities. ${ }^{9}$ Reference lists were examined for pertinent articles missed by the search strategy. Articles were retrieved in both official languages.

\section{Inclusion and exclusion criteria}

We included reports of empirical research in Canada that examined injury associated with a consumer product and provided some numerical estimate of importance but excluded commentaries and editorials. Review articles were used as a source of additional references that may have been missed in the initial search, but were not included with the empirical material.

\section{Indices for identifying risk management priorities}

After examining all the research retrieved, we selected six indices to assist in identifying priorities for injury reduction. These were (1) approximate annual number of injuries (estimated by dividing the number of injuries reported by the time period covered); (2) relative severity of the injury expressed in terms of percentage of injured people admitted to hospital; (3) reported trends; (4) proportion of injuries caused by the product itself (e.g. defects); (5) proportion of injuries caused by inappropriate or risky use (CHIRPP records circumstances surrounding the injury, e.g. excessive speed or jumping off the top bunk); and (6) the proportion of injured people who were not using a helmet at the time of the injury (where helmet use is considered appropriate, and where recorded). We highlighted for consideration as priorities those consumer products associated with about 500 or more injuries annually, $20 \%$ or more of injured people admitted to hospital, an increasing trend, $5 \%$ or more of injuries attributable to the product itself, $50 \%$ or more of injured people using the product inappropriately or recklessly, and $50 \%$ or more of injured people who were not using a helmet. Cut points on the indices were chosen arbitrarily to identify between five and ten consumer products each. Consumer products for which injuries were either the most numerous or more serious and which met at least one of the four remaining criteria were selected for consideration as priorities for risk management.

\section{Results}

The database search located 703 records after removal of duplicates. Of these, 46 reports met our inclusion criteria of original quantitative empirical research (Table 1). Within the resource and time constraints for this project, full articles were obtained for 37 of these. We used information in the abstract for the remaining nine reports. Abstract-only articles were retained in order to avoid any bias associated with using only references for which the whole article could be obtained and also to enable further attempts to locate the full article. In addition, 32 online reports from CHIRPP were retrieved from the Internet using the same search terms and augmented the data retrieved from the literature database search. 
TABLE 1

Selected characteristics of injuries associated with consumer products

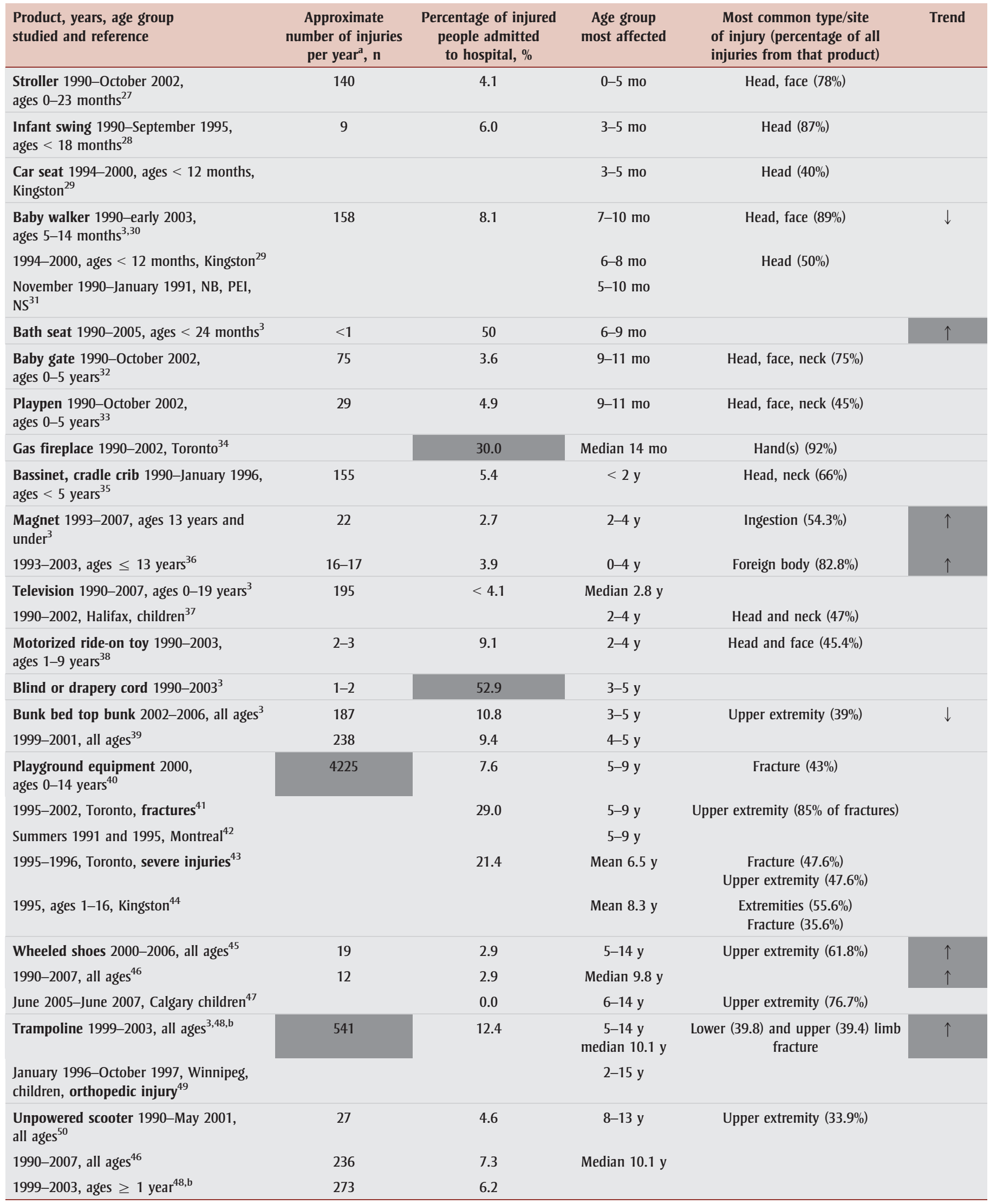

Continued on the following pages 
TABLE 1 (continued)

Selected characteristics of injuries associated with consumer products

\begin{tabular}{|c|c|c|c|c|c|}
\hline $\begin{array}{l}\text { Product, years, age group } \\
\text { studied and reference }\end{array}$ & $\begin{array}{c}\text { Approximate } \\
\text { number of injuries } \\
\text { per year }{ }^{\mathrm{a}}, \mathrm{n}\end{array}$ & $\begin{array}{l}\text { Percentage of injured } \\
\text { people admitted } \\
\text { to hospital, } \% \\
\end{array}$ & $\begin{array}{l}\text { Age group } \\
\text { most affected }\end{array}$ & $\begin{array}{l}\text { Most common type/site } \\
\text { of injury (percentage of all } \\
\text { injuries from that product) }\end{array}$ & Trend \\
\hline June 2005-June 2007, Calgary children ${ }^{47}$ & & & $6-9 y$ & Upper extremity (54.3\%) & \\
\hline $\begin{array}{l}\text { Swimming pool (drowning or near drown- } \\
\text { ing) } 1990-2003 \text {, ages } 0-14 \text { years }\end{array}$ & 46 & 57.1 & $<4 \mathrm{y}$ & & \\
\hline (entrapments) 1990-2003, all ages ${ }^{52}$ & $2-3$ & 5.7 & $10-14 y$ & Foot $(57 \%)$ & \\
\hline $\begin{array}{l}\text { Fireworks, fire crackers and sparklers June } \\
\text { 1998-March 2004, all ages }{ }^{33}\end{array}$ & $16-17$ & 7.4 & $10-14 y$ & Upper extremities (46\%) & \\
\hline In-line skates 1998, all ages ${ }^{54}$ & 962 & 7.8 & $10-14 y$ & Fracture $(47.6 \%)$ & \\
\hline 1999-2003, ages $\geq 1$ year $^{48, b}$ & 763 & 7.5 & & & \\
\hline 1990-2007, all ages ${ }^{46}$ & 657 & 6.9 & Median $11.9 \mathrm{y}$ & & \\
\hline June 2005-June 2007, Calgary children ${ }^{47}$ & & & $10-14$ y & Upper extremity (55.1\%) & \\
\hline Bicycle 2006 , ages $\geq 1$ year $^{55}$ & 3993 & 11.0 & $11-15$ y & Upper extremity (44.0\%) & \\
\hline 1990-2007, all ages ${ }^{46}$ & 4726 & 10.7 & Median $11.0 \mathrm{y}$ & & \\
\hline 1999-2003, ages $\geq 1$ year $^{48, b}$ & 3189 & 10.2 & & & \\
\hline 1994, ages 0-19, Kingston and area ${ }^{25}$ & & & $5-14 y$ & & \\
\hline 1994-1998, children ${ }^{26}$ & 2342 & & & & \\
\hline 1986-1991, Ontario fatalities ${ }^{56}$ & & & $\begin{array}{l}15-44 \text { y } \\
\text { mean } 26 y\end{array}$ & Head $(75 \%)$ & \\
\hline June 2005-June 2009, Calgary children ${ }^{47}$ & & 5.4 & $10-14 y$ & Upper extremity (49.1\%) & \\
\hline $\begin{array}{l}\text { 1993-2002, Halifax, children } \\
\leq 15 \text { years }^{57}\end{array}$ & & 9.6 & $6-13$ y & Shoulder/arm (48.2\%) & \\
\hline Go-cart 2000-2002, ages $\geq 5$ years $^{58}$ & 45 & 6.0 & $10-14$ y & $\begin{array}{l}\text { Head, face, neck }(32.1 \%) \\
\text { Upper extremity }(32.1 \%)\end{array}$ & \\
\hline 1990-2007, all ages ${ }^{59}$ & 40 & 8.2 & Median 11.9 y & & \\
\hline $\begin{array}{l}\text { Powered scooter } 1998-2005 \\
\text { ages } \geq 7 \text { years }^{60}\end{array}$ & 5 & 15.0 & $10-19 y$ & Upper extremity (57.5\%) & $\uparrow$ \\
\hline 1990-2007, all ages ${ }^{59}$ & $3-4$ & 15.3 & Median 12.3 y & & \\
\hline Sled $2000-2002$, ages $\geq 5$ years $^{61}$ & 855 & 9.2 & $5-14$ y & Fracture $(37.7 \%)$ & \\
\hline Winter $2001-2002^{62}$ & 1027 & 10.5 & $5-14$ y & $\begin{array}{l}\text { Upper }(32.3 \%) \text { and lower }(28.0 \%) \\
\text { extremity and head, face, neck (29.8\%) }\end{array}$ & \\
\hline 1999-2003 ages $\geq 1$ year $^{48, b}$ & 759 & 9.4 & & & \\
\hline April 1997-March 1999, Edmonton ${ }^{63}$ & & 11.0 & Median $12 \mathrm{y}$ & $\begin{array}{c}\text { Lower }(32 \%) \text { and upper }(30 \%) \\
\text { extremity }\end{array}$ & \\
\hline $\begin{array}{l}1 \text { December, 1992-24 March, 1993, } \\
\text { Sudbury }{ }^{64}\end{array}$ & & 7.0 & Mean 16 y & Extremity $(49 \%)$ & \\
\hline Ice skates $2000-2002$, ages $\geq 5$ years $^{61}$ & 866 & 4.0 & $5-14 y$ & Fracture $(32.4 \%)$ & \\
\hline 1999-2003 ages $\geq 1$ year $^{48, b}$ & 760 & 3.2 & & & \\
\hline Skateboard 1990-2007, all ages ${ }^{46}$ & 755 & 6.7 & Median $13.5 \mathrm{y}$ & & \\
\hline 1999-2003 ages $\geq 1$ year $^{48, b}$ & 1001 & 7.3 & & & \\
\hline June 2005-June 2007, Calgary children ${ }^{47}$ & & & $10-14$ y & Upper extremity (53.7\%) & \\
\hline Snowboard $2000-2002$, ages $\geq 5$ years $^{61}$ & 1471 & 11.3 & $10-14 y$ & Fracture $(57.7 \%)$ & \\
\hline April 2000-March $2001^{65}$ & 1177 & 17.2 & & Upper limb fracture (51.3\%) & $\uparrow$ \\
\hline 1999-2003 ages $\geq 1$ year $^{48, b}$ & 1262 & 12.0 & & & \\
\hline Snowshoes $2000-2002$, ages $\geq 5$ years $^{61}$ & 4 & 0.0 & $10-14 y$ & Fracture $(38.5 \%)$ & \\
\hline Snowblades $2000-2002$, ages $\geq 5$ years $^{61}$ & 35 & 10.6 & $10-14$ y & Fracture $(54.8 \%)$ & \\
\hline $\begin{array}{l}\text { Dirt bike } 1993-2002, \text { Halifax, } \\
\text { children } \leq 15 \text { years }^{57}\end{array}$ & 158 & $\approx 20.0$ & $10-15 y$ & Shoulder/arm (50.6\%) & \\
\hline 1990-2007, all ages 59 & & 25.7 & Median $14.4 \mathrm{y}$ & & $\uparrow$ \\
\hline
\end{tabular}

Continued on the following pages 
TABLE 1 (continued)

Selected characteristics of injuries associated with consumer products

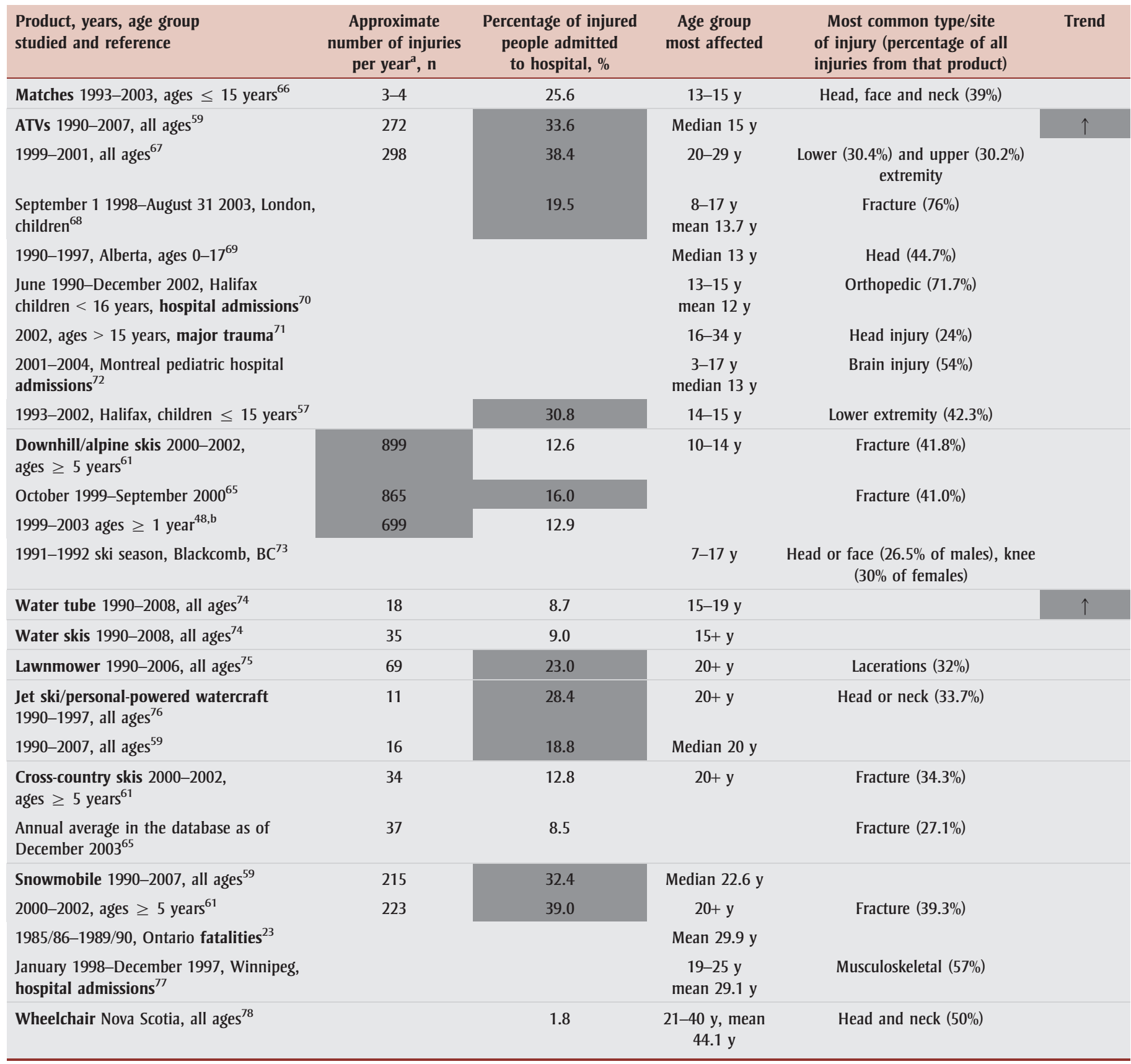

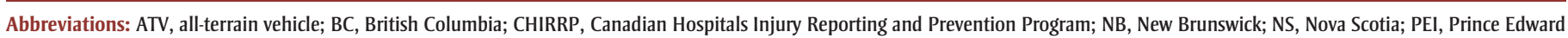
Island.

Note: Highlighted items are associated with 500 or more injuries per year, have hospitalization rates of $20 \%$ or higher, and injuries are increasing.

a Data from CHIRRP.

${ }^{\mathrm{b}}$ Article about trampolines includes comparison with other recreation-related equipment.

Table 1 summarizes the results of the systematic literature review by consumer product in terms of estimated annual numbers of injuries, percentage of injured admitted to hospital, most common type/ site of injury and any reported trend. The results are ordered approximately by age group most affected, from youngest to oldest.

From the literature reviewed, in which injuries to children and teenagers predominate, outdoor play and sports equipment appear to be associated with the greatest numbers of injuries. Playground equipment (e.g. swings, monkey bars, slides, teeter-totters) and bicycles are related to more than 3000 injuries per year each. Downhill winter activities using sleds, snowboards and skis are the next most common at about 1000 injuries per 
year each. Other consumer products that are involved with between 500 and 1000 injuries per year are skateboards, in-line skates, ice skates and trampolines.

Consumer products used around the home play a more important role in terms of injury severity than absolute numbers. Injury severity is defined here in terms of the proportion of the injured who are admitted to hospital. Although hospitalization rates can serve as a proxy for severity of injury across consumer products, the fact that CHIRPP data do not include information on people who died without being taken to hospital likely underestimates the severity of some types of consumer product-related injury. Over half of children injured by a blind or drapery cord or in a swimming pool are admitted to hospital, as are $25 \%$ to $30 \%$ of children burned by gas fireplaces or matches and over $20 \%$ of people injured by a lawnmower. Beyond the home, consumer products most likely to be related to serious injury are powered recreational equipment such as ATVs and snowmobiles (over $30 \%$ of injured admitted to hospital), personal-powered watercraft and dirt bikes (over 20\% admitted to hospital).

Consumer products for which the numbers of injuries may be on the rise include infant bath seats, trampolines, wheeled shoes, powered scooters, ATVs, dirt bikes, snowboards, water tubes and magnets.

Tables 2 through 4 show the circumstances related to the injury. Because most of the research describing injury circumstances is based on CHIRPP data, consumer products used by children and youth predominate. From the available data, it appears that injuries related to product characteristics are relatively rare (Table 2). Baby swings appear to be the product most often at fault with $12.0 \%$ of injuries attributable to the product itself, followed by wheeled shoes (7.6\%), powered scooters $(7.5 \%)$, playground equipment $(6.6 \%)$, cribs, cradles or bassinets $(5.7 \%)$, playpens $(3.8 \%)$, baby gates $(3.4 \%)$, motorized ride-on toys (3.0\%), bunk beds (1.4\%) and unpowered scooters $(1.0 \%)$.

A relatively high proportion of injuries result from inappropriate or risky use of a product (Table 3 ). For magnets, almost all of the injuries $(93.9 \%)$ appear to be the result of risky or inappropriate use (e.g. ingestion or insertion in the nose). About three-quarters of injuries from snowmobile accidents can be attributed to alcohol impairment or excessive speed. Alcohol impairment is implicated in just over half of ATV-related injuries. Over $70 \%$ of injuries from matches result from inap- propriate use (e.g. playing with or ingestion). Leaving a child alone in a bath seat is likely the single most common reason for a related injury, accounting for $60.0 \%$ of injuries from bath seats. Other injury causes are leaving a baby gate open or not secured (43.4\% of injuries), playing, jumping, standing or being pushed from a top bed bunk (40.5\%), and lack of a barrier at the top of stairs when a baby is in a walker $(24.7 \%)$.

The only type of protective gear for which data were available across some products was helmet use. Almost everyone (over $90 \%$ ) injured while sledding, using wheeled shoes or a personal-powered watercraft were not wearing a helmet (Table 4). Approximately one-half to three-quarters of people injured while downhill skiing, snowboarding, or using an unpowered scooter or in-line skates were not using a helmet. A considerable proportion of those injured while using powered recreational equipment were also not wearing a helmet. For bicycles and ATVs, helmet non-use percentages were available by severity of injury. Almost everyone who was killed in a bicyclerelated accident was not wearing a helmet, and for ATV-related injuries, non-use of a helmet occurred in a greater proportion of cases requiring hospital admission or where there was major trauma.

TABLE 2

Proportions of injuries caused by product characteristics

\begin{tabular}{|c|c|c|c|}
\hline Product & $\begin{array}{l}\text { Percentage of injuries caused } \\
\text { by product failure, } \%\end{array}$ & $\begin{array}{l}\text { Percentage of injuries caused } \\
\text { by body entrapment, } \%\end{array}$ & $\begin{array}{l}\text { Total percentage of injuries attribu- } \\
\text { table to product characteristics, } \%\end{array}$ \\
\hline Baby swing & $12.0^{28}$ & & 12.0 \\
\hline Wheeled shoes & $7.6^{45}$ & & 7.6 \\
\hline Powered scooter & $7.5^{60}$ & & 7.5 \\
\hline Playground equipment & $2.2^{44, \mathrm{a}}$ & $4.4^{44}$ & 6.6 \\
\hline Crib, cradle, bassinet & $1.3^{35, \mathrm{~b}}$ & $4.4^{35}$ & 5.7 \\
\hline Baby gate & $1.2^{32}$ & $2.2^{32}$ & 3.4 \\
\hline Motorized ride-on toy & $3.0^{38}$ & & 3.0 \\
\hline Bunk bed & $1.2^{39}$ & $0.2^{3}$ & 1.4 \\
\hline Unpowered scooter & $1.0^{50}$ & & 1.0 \\
\hline In-line skates & $0.5^{54}$ & & 0.5 \\
\hline
\end{tabular}

a Rough edge.

b Includes $0.3 \%$ caused by child eating the wood or being injured by splinters. 
TABLE 3

Proportions of injuries caused by inappropriate or risky use of a product

\begin{tabular}{llc} 
Product & \multicolumn{1}{c}{$\begin{array}{c}\text { Types of risky or } \\
\text { inappropriate use }\end{array}$} & $\begin{array}{c}\text { Percentage of injuries caused by } \\
\text { risky or inappropriate use, \% }\end{array}$ \\
\hline Magnet & Ingestion, insertion in nose or ear & $93.9^{3}$ \\
Snowmobile & Impaired & $69.0^{23, a} ; 70.0-88.0^{77}$ \\
Matches & Excessive speed & $82.0^{77}$ \\
Bath seat & Playing with or ingesting & $71.8^{66}$ \\
All-terrain vehicle & Leaving child alone in seat & $60.0^{3}$ \\
Baby gate & Impaired & $\leq 56.0^{71, \mathrm{~b}}$ \\
Bunk bed (top bunk) & Left open or unsecured & $43.4^{32}$ \\
Baby walker & Playing, jumping and standing, being pushed & $40.5^{3}$ \\
Bicycle & Lack of a barrier at the top of stairs & $24.7^{30}$ \\
\hline
\end{tabular}

${ }^{a}$ Deaths.

b Major trauma.

None of the 41 products included in Table 1 was identified by all priority indices, but 26 products were identified by at least one (Table 5). Assuming that priorities are likely to focus on products where injuries are either the most common or the most serious, this table identifies 18 products that fall into one or the other category. The 9 products associated with the most injuries differ from the 9 that result in a higher proportion of hospital admissions. Further selection of products based on at least one other index reduces the prioritized products to 11 , that is, 6 that result in a high number of injuries and 5 that appear to result in more serious injuries requiring hospitalization.

Table 6 highlights consumer products and areas of concern. Of the 6 products associated with a high number of injuries, 4-in-line skates, sleds, snowboards and downhill skis-are associated with a relatively low proportion of helmet use.

\section{Discussion}

Systematic literature reviews are prone to both reporting bias (the tendency for

TABLE 4

Non-use of helmets among injured people by product

\begin{tabular}{lc} 
Consumer product & \% of injuries where a helmet was not used \\
\hline Sled & $99.0 \%^{64} ; 93 \%^{63}$ \\
Wheeled shoes & $95.4^{47} ; 87.3^{46}$ \\
Jet ski/personal-powered watercraft & $90.9^{59}$ \\
Skis and snowboard & $79.1 \%^{80}$ \\
Skateboard & $73.7^{47} ; 67.9^{46}$ \\
Unpowered scooter & $72.4^{50} ; 66.3^{47} ; 57.6^{46}$ \\
In-line skates & $56.8^{47} ; 50.5^{54} ; 49.6^{46}$ \\
Snowmobile & $43.1^{59}$ \\
Go-cart & $39.6^{58} ; 17.8^{59}$ \\
Powered scooter & $38.9^{59}$ \\
Bicycle & $37.3^{55} ; 29.8^{46} ; 15.4^{47} ; 96.0^{56, a}$ \\
All-terrain vehicle & $12.7^{59}$ \\
Dirt bike & $29.0^{59} ; 28.2^{67} ; 35.0^{68, b} ; 84^{71, b} ; 84^{72, c} ; 31.7^{70, c}$ \\
\hline
\end{tabular}

a Fatalities.

b Major trauma.

c Pediatric hospital admissions.

statistically significant results to be reported over results that show no association) and publication bias (the greater likelihood that reports showing statistical significance will be published). This review has attempted to deal with these sources of bias by including both published and unpublished information and articles for which only the abstract was located. A further source of bias can arise from the choice of search terms. Despite every attempt to make this review as comprehensive as possible within the resource constraints, we acknowledge that searching for each individual consumer product (sometimes with different names such as jet ski or personal-powered watercraft) would have been a more exhaustive approach than using the generic term "consumer product," which some publications may not have used as a keyword.

"Grey literature" (i.e. literature not included in the databases searched) was partially addressed by including online publications (all of which used CHIRPP data); however, the fact that we did not search for government publications in each of the Canadian provinces means that we may have missed some relevant material. ${ }^{10-14}$ We assumed that the national reports using CHIRPP data would have included the data used in provincial reports.

The topic of injury associated with consumer products does not lend itself well to the classical systematic literature review for at least two reasons. First, epidemiological studies often take years to design, carry out, write up and publish in scientific journals; therefore, published epidemiological reports likely will not represent those products where incident reports result in early recalls. Second, a literature review that spans several years may not be relevant to today's hazards, in that dangerous products may already have been recalled and are no longer available and new products and designs have appeared. For example, missing in the results of this search are potentially harmful effects of personal electronic devices. An example is hearing loss associated with MP3 players. ${ }^{15}$ 
TABLE 5

Combined priority indices from Tables 1 to 4

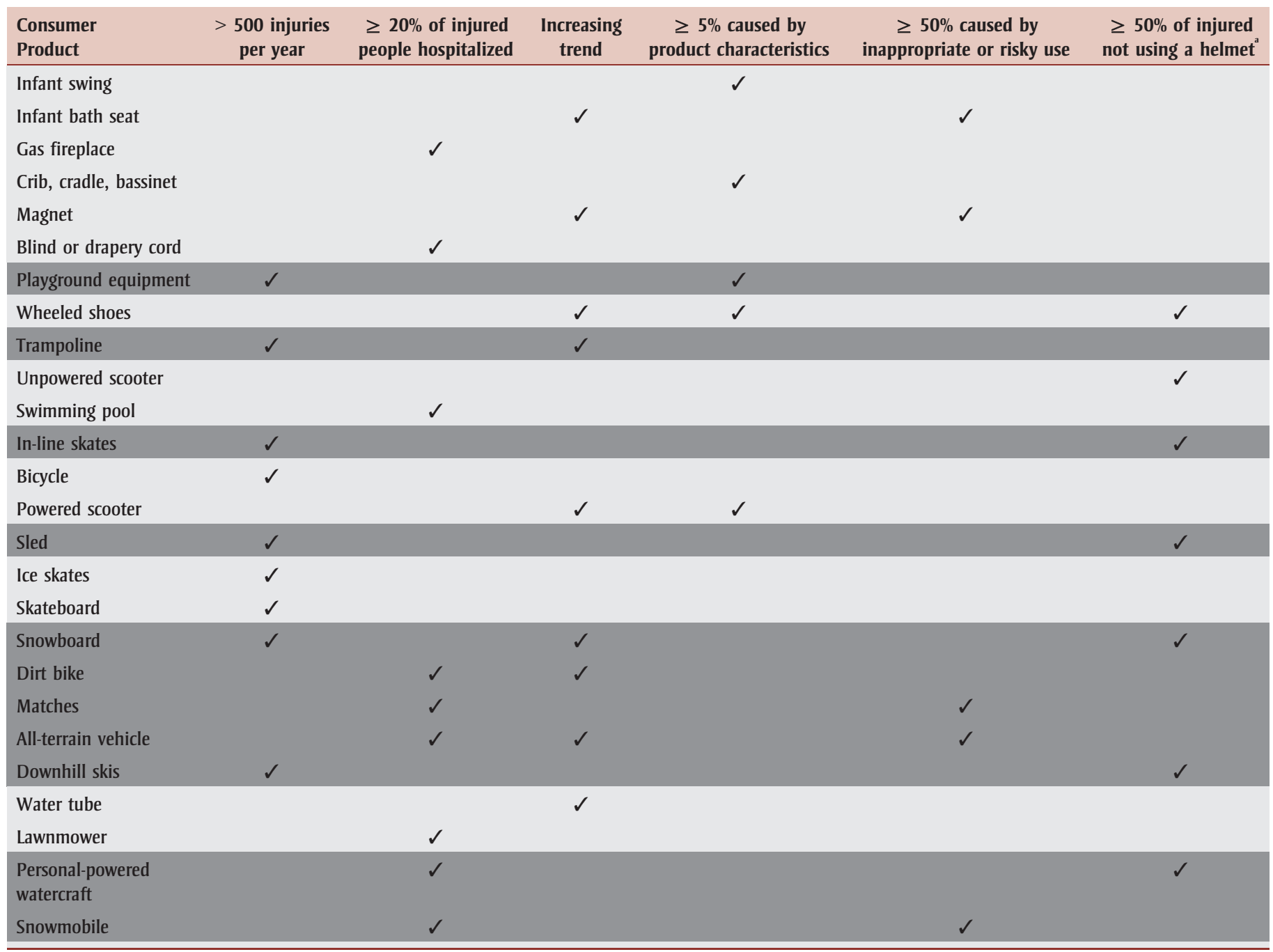

Note: Highlighted products are those that are most numerous or serious and have values that exceed the cut-point on at least one other priority index.

${ }^{\text {a }}$ Where helmet use is considered appropriate and where reported.

Since the bulk of CHIRPP data comes from hospitals in cities, and most are pediatric hospitals, injuries suffered by older teen-

TABLE 6

\section{Consumer products and areas of concern}

\begin{tabular}{ll} 
Issue & Consumer Product \\
\hline Helmet non-use & In-line skates \\
& Sleds \\
& Snowboards \\
& Downhill skis \\
& Personal-powered watercraft \\
& All-terrain vehicles \\
Use while impaired & Snowmobiles \\
& Snowmobiles \\
Excessive speed & Playground equipment (includes surface material) \\
Product design & Matches \\
\hline Inappropriate storage and use &
\end{tabular}

areas are under-represented in the CHIRPP database. In addition, not all provinces and territories have hospitals participating in CHIRPP (e.g. Saskatchewan, New Brunswick, Prince Edward Island, Yukon, Northwest Territories, Nunavut). Fatal injuries are also under-represented because CHIRPP does not capture information about people who died before they could be taken to hospital. ${ }^{2}$ Studies that have assessed the representativeness of CHIRPP data indicate other biases. Sensitivity ranged from $30 \%$ to $91 \%$ across some hospitals; ${ }^{16}$ injuries among older children were more likely to be missed in some hospitals ${ }^{17,18}$ but not others; ${ }^{16}$ and more serious injuries (e.g. those admitted to hospital) were less likely 
to be missed in some hospitals ${ }^{17,18}$ and more likely to be missed in others. ${ }^{16}$ However, the data collected have been found to be both reliable and valid. ${ }^{19}$

Future efforts to look at consumer products and injuries in Canada may wish to focus on the following:

\section{Population attributable risk}

One possible approach would involve using the approximate number of injuries per year along with the prevalence of modifiable risk factors (e.g. non-use of helmets) to estimate the population attributable risk reduction of specific interventions. Such an estimate of the potential public health benefit could be used as the basis for setting priorities. However, this approach would likely require a meta-analysis based on a subset of articles with data suitable for pooling and/or the use of raw data from the CHIRPP database.

\section{Exposure-based risk estimates}

Although this review identifies those types of products associated with the greatest numbers of injuries, the absolute number of injuries is a function of both the availability of a given product and the risk of injury related to the product. To illustrate, does the fact that there are three to four times as many injuries associated with bicycles as with in-line skates indicate that cycling is riskier, that there are more bicycles than in-line skates or that people spend more time cycling than using in-line skates? Likely, it is a combination of all three factors. With a few exceptions, the studies cited here have not provided estimates of risk of injury relative to exposure to a product, which is necessary to identify particularly hazardous products and their associated activities. The difficulty in providing comparative estimates of risk lies in finding suitable denominators. In the future, for at least some types of consumer products, calculations of injury rates in relation to exposure may be possible. Methods similar to those used by others ${ }^{20-23}$ could be used to relate CHIRPP data to survey data, such as the physical activity of youth and adults collected in the Canadian Health Measures Survey, ${ }^{24}$ to estimate risk in relation to exposure. Another approach would be to combine injury data with sales data to give an estimate of risk based on the availability of certain consumer products.

\section{Population-based injury rates}

The studies cited here involved different age groups, in different locations and over different time periods, making comparisons of injury rates across products difficult. The CHIRPP database permits the calculation of injury rates in relation to the total number of injuries in the database (overall or for a particular age stratum); however, these rates only approximate population rates, in that people in the CHIRPP database likely do not represent the entire population from which they are drawn. CHIRPP data could be related to Census data to estimate the validity of the former method for estimating population rates (crude and adjusted) and to allow comparisons across products and with other studies where population rates have been used. ${ }^{25,26}$

\section{Age-specific rates}

Although this review was able to identify the age groups most affected by injury related to specific consumer products, it could not identify the products most likely to be associated with injury for specific age groups throughout the lifespan. The CHIRPP dataset could be used to provide this information, which would assist priority-setting and injury reduction strategies in relation to specific age groups.

\section{Conclusions}

Despite its acknowledged limitations, this systematic literature review has provided a broad look at the problem of injury related to specific consumer products in Canada in terms of injury frequency, severity, possible trends, and likely causes. The most numerous injuries appear to involve playground equipment and bicycles; the most serious injuries occur around the home or while using powered recreational equipment; injuries related to several consumer products may be increasing; and the most frequent causes of injury appear to be behavioural (i.e. inappropriate or risky use and insufficient safety precautions, such as helmet use), rather than the fault of the product itself. The analysis presented here identified the following areas of concern regarding consumer products and injuries: (1) lack of helmet use by people using in-line skates, sleds, snowboards, downhill skis and personal-powered watercraft; (2) the operation of ATVs and snowmobiles by people who are impaired by alcohol; (3) the operation of snowmobiles at excessive speeds; (4) poor design of playground equipment; and (5) non-secure storage and use of matches.

\section{Acknowledgements}

The authors wish to thank Jane Falconer, Information Services Librarian at the London School of Hygiene \& Tropical Medicine, UK, for her invaluable contribution to the design of the literature search strategy.

\section{References}

1. Mo F, Choi BC, Clottey C, LeBrun B, Robbins G. Characteristics and risk factors for accident injury in Canada from 1986 to 1996: an analysis of the Canadian Accident Injury Reporting and Evaluation (CAIRE) database. Inj Control Saf Promot. 2002 Jun;9(2):73-81.

2. Canadian Hospitals Injury Reporting and Prevention Program (CHIRPP) [Internet]. Ottawa (ON): Public Health Agency of Canada; [updated 2009 Apr 22; cited 2012 Feb 19]. Available from: http://www.phac -aspc.gc.ca/injury-bles/chirpp/index-eng.php

3. Child and youth injury in review: 2009 edition - Spotlight on consumer product safety. Ottawa (ON): Public Health Agency of Canada; 2009. [Catalogue No.: Cat: HP15-5/2009E-PDF]

4. Canada Consumer Product Safety Act, Stat S.C. 2010 , c. 21.

5. Motor Vehicle Safety Act, Stat S.C. 1993, c. 16.

6. Playground equipment [Internet]. Ottawa (ON): Health Canada; 2010 [updated 2010 Sep 8; cited 2012 Dec 6]. Available from: http://www.hc-sc.gc.ca/cps-spc/sport/equip -play-jeu/index-eng.php 
7. ICD-10 version: 2010 [Internet]. Geneva (CH): World Health Organization; 2010 [updated 2012 Jan 4; cited 2012 Feb 19]. Available from: http://apps.who.int /classifications/icd10/browse/2010/en

8. Injury reports [Internet]. Ottawa (ON): Public Health Agency of Canada; [updated 2010 Sep 30; cited 2012 Feb 19]. Available from: http://www.phac-aspc.gc.ca/injury -bles/chirpp/injrep-rapbles/index-eng.php

9. Centre for Surveillance Coordination, Population and Public Health Branch. Inventory of injury data sources and surveillance activities. Ottawa (ON): Public Health Agency of Canada; 2005.

10. O'Reilly-Fromentin ME, Rainville M. Portrait des traumatismes liés aux appareils de jue: données schirpt de L'hôpital de L'Enfant-Jésus de juillet 1997 à juin 2001. Québec (QC): Institut national de santé publique du Québec; 2004 May.

11. Rainville M. Traumatismes d'origine récréative et sportive: portrait des consultations à l'urgence de l'Hôpital de L'EnfantJésus de Québec - De juillet 1997 à juin 2001. Québec (QC): Institut national de santé publique du Québec; 2004 August.

12. Rainville M, Goulet C, Tremblay B, Maurice P. Blessures en surf des neiges: portrait des consultations à l'urgence de l'Hôpital de l'Enfant-Jésus de Québec entre juin 2003 et décembre 2005. Québec (QC): Institut national de santé publique du Québec; 2010.

13. Rainville M, Goulet C, Tremblay B, Pierre M. Blessures en Planche à Roulettes: portrait des consultations à l'urgence de l'Hôpital de l'Enfant-Jésus de Québec entre juin 2003 et décembre 2007. Québec (QC): Institut national de santé publique du Québec; 2010.

14. Légaré G. Traumatismes associés à l’utilisation des trottinettes au Québec. Bulletin épidémiologique hebdomadaire. 2002;38: 186-7.

15. Montoya FS, Ibarguen AM, Vences AR, Rey ASD, Fernandez JMS. Evaluation of cochlear function in normal-hearing young adults exposed to MP3 player noise by analyzing transient evoked otoacoustic emissions and distortion products. $\mathrm{J}$ Otolaryngol Head Neck Surg. 2008; 37(5):718-24.
16. Macarthur C, Pless IB. Evaluation of the quality of an injury surveillance system. Am J Epidemiol. 1999 Mar 15;149(6):58692.

17. Macarthur C, Pless IB. Sensitivity and representativeness of a childhood injury surveillance system. Inj Prev. 1999 Sep; $5(3): 214-6$

18. Macpherson AK, White HL, Mongeon S, Grant VJ, Osmond M, Lipskie $\mathrm{T}$, et al. Examining the sensitivity of an injury surveillance program using populationbased estimates. Inj Prev. 2008 Aug; $14(4): 262-5$

19. Macarthur C, Dougherty G, Pless IB. Reliability and validity of proxy respondent information about childhood injury: an assessment of a Canadian surveillance system. Am J Epidemiol. 1997 May 1;145(9):834-41.

20. Hagel BE, Pless B, Platt RW. Trends in emergency department reported head and neck injuries among skiers and snowboarders. Can J Public Health. 2003 NovDec;94(6):458-62.

21. Aultman-Hall L, Kaltenecker MG. Toronto bicycle commuter safety rates. Accid Anal Prev. 1999 Nov;31(6):675-86.

22. Hu X, Wesson DE, Chipman ML, Parkin PC. Bicycling exposure and severe injuries in school-age children: a population-based study. Arch Pediatr Adolesc Med. 1995; 149(4):437-41.

23. Rowe B, Milner R, Johnson C, Bota G. Snowmobile-related deaths in Ontario: a 5 year review. CMAJ. 1992;146(2):147-52.

24. Statistics Canada. Canadian Health Measures Survey: physical activity of youth and adults [Internet]. Ottawa (ON): Government of Canada; [updated $2011 \mathrm{Jul}$ 5; cited 2012 Feb 19]. Available from: http://www.statcan.gc.ca/daily-quotidien/ 110119/dq110119b-eng.htm

25. Bienefeld M, Pickett W, Carr PA. A descriptive study of childhood injuries in Kingston, Ontario, using data from a computerized injury surveillance system. Chronic Dis Can. 1996;17(1):21-7.
26. Macpherson AK, To TM, Parkin PC, Moldofsky B, Wright JG, Chipman ML, et al. Urban/rural variation in children's bicycle-related injuries. Accid Anal Prev. 2004 Jul;36(4):649-54.

27. CHIRPP - Canadian Hospitals Injury Reporting and Prevention Program: data sampler: stroller related head and face injuries: CHIRPP database, cumulative to October 2002, 0-23 months, 1751 records [Internet]. Ottawa (ON): Public Health Agency of Canada; [cited 2012 Feb 19]. Available from: http://www.phac-aspc .gc.ca/injury-bles/chirpp/injrep-rapbles/pdf /strollers_e.pdf

28. CHIRPP injury reports: injuries associated with infant swings: entire CHIRPP database, as of September 1995, aged under 18 months [Internet]. Ottawa (ON): Public Health Agency of Canada; [updated 1996 Jul 10; cited 2012 Feb 19]. Available from: http://www.phac-aspc.gc.ca/injury-bles /chirpp/injrep-rapbles/irinsw-eng.php

29. Pickett W, Streight S, Simpson K, Brison RJ. Injuries experienced by infant children: a population-based epidemiological analysis. Pediatrics. 2003 Apr;111(4):e365-70.

30. Canadian Hospitals Injury Reporting and Prevention Program. CHIRPP injury brief: injuries associated with baby walkers 1990early 2003, ages 5-14 months [Internet]. Ottawa (ON): Public Health Agency of Canada; [cited 2012 Feb 19]. Available from: http://www.phac-aspc.gc.ca/injurybles/chirpp/pdf/CHIRPP_INJURY_BRIEF -Baby_Walkers-NOV_UPD.pdf

31. Walker JM, Breau L, McNeill D, Rogers B, Sweet K. Hazardous baby walkers: a survey of use. Pediatr Phys Ther. 1996;8(1):25-30.

32. CHIRPP - Canadian Hospitals Injury Reporting and Prevention Program: data sampler: injuries associated with baby gates: CHIRPP database, cumulative to October 2002, ages 0-5, 940 records [Internet]. Ottawa (ON): Public Health Agency of Canada; [cited 2012 Feb 19]. Available from: http://www.phac-aspc .gc.ca/injury-bles/chirpp/injrep-rapbles/pdf /babygates_e.pdf 
33. CHIRPP - Canadian Hospitals Injury Reporting and Prevention Program: data sampler: injuries associated with playpens: CHIRPP database, cumulative to October 2002, 0-5 years - 368 records [Internet]. Ottawa (ON): Public Health Agency of Canada; [cited 2012 Feb 19]. Available from: http://www.phac-aspc.gc.ca/injury -bles/chirpp/injrep-rapbles/pdf/playpens _e.pdf

34. Zettel JC, Khambalia A, Barden W, Murthy T, Macarthur C. Gas fireplace contact burns in young children. J Burn Care Rehabil. 2004 Nov-Dec;25(6):510-2.

35. CHIRPP injury reports: injuries associated with cribs, cradles and bassinets: entire CHIRPP database, as of February 1996, under 5 years of age [Internet]. Ottawa (ON): Public Health Agency of Canada; [updated 1997 Nov 6; cited 2012 Feb 19]. Available from: http://www.phac-aspc .gc.ca/injury-bles/chirpp/injrep-rapbles /crib3-eng.php

36. CHIRPP injury report: injuries associated with magnets: 1993-2003, 13 years and under [Internet]. Ottawa (ON): Public Health Agency of Canada; [updated 2012 Feb 2; cited 2012 Feb 19]. Available from: http://www.phac-aspc.gc.ca/injury-bles /chirpp/injrep-rapbles/magnets-aimants07-eng .php

37. Dotchin SA, Gordon KE. The terrible truth about toppling televisions. Paediatr Child Health. 2007;12(3):221-4.

38. Canadian Hospitals Injury Reporting and Prevention Program. CHIRPP injury brief: injuries associated with motorized ride-on toys 2007: CHIRPP, as of September 2006, ages 1-9 years [Internet]. Ottawa (ON): Public Health Agency of Canada; [cited 2012 Feb 19]. Available from: http://www .phac-aspc.gc.ca/injury-bles/chirpp/injrep -rapbles/pdf/bmr-vjm-eng.pdf

39. CHIRPP - Canadian Hospitals Injury Reporting and Prevention Program: data sampler: injuries associated with bunk beds: CHIRPP database, 1999-2001, all ages - 982 records [Internet]. Ottawa (ON): Public Health Agency of Canada; [cited 2012 Feb 19]. Available from: http://www .phac-aspc.gc.ca/injury-bles/chirpp/injrep -rapbles/pdf/bunk_bed_e.pdf
40. CHIRPP - Canadian Hospitals Injury Reporting and Prevention Program: data sampler: injuries associated with playground equipment: CHIRPP database, 2000, ages 0-14 years - 4,225 records [Internet]. Ottawa (ON): Public Health Agency of Canada; [cited 2012 Feb 19]. Available from: http://www.phac-aspc .gc.ca/injury-bles/chirpp/injrep-rapbles/pdf /playground_e.pdf

41. Fiissel D, Pattison G, Howard A. Severity of playground fractures: play equipment versus standing height falls. Inj Prev. 2005; 11(6):337-9.

42. Laforest S, Robitaille Y, Lesage D, Dorval D. Surface characteristics, equipment height, and the occurrence and severity of playground injuries. Inj Prev. 2001 Mar;7(1):3540.

43. Macarthur C, Hu XH, Wesson DE, Parkin PC. Risk factors for severe injuries associated with falls from playground equipment. Accid Anal Prev. 2000;32(3):377-82.

44. Mowat DL, Wang F, Pickett W, Brison RJ. A case-control study of risk factors for playground injuries among children in Kingston and area. Inj Prev. 1998 Mar;4(1):39-43.

45. Canadian Hospitals Injury Reporting and Prevention Program. CHIRPP injury brief: injuries associated with wheeled shoes ("Heelys"): CHIRPP, 2002-2006, all ages [Internet]. Ottawa (ON): Public Health Agency of Canada; [cited 2012 Feb 19]. Available from: http://www.phac-aspc .gc.ca/injury-bles/chirpp/injrep-rapbles/pdf /heely-eng.pdf

46. Injury and Child Maltreatment Section, Health Surveillance and Epidemiology Division. Emergency department surveillance injuries associated with wheeled, non-motorized devices: The Canadian Hospitals Injury Reporting and Prevention Program (CHIRPP), all ages, 1990-2007 [Internet]. Ottawa (ON): Public Health Agency of Canada; [cited 2012 Feb 19]. Available from: http://www.phac-aspc .gc.ca/injury-bles/chirpp/injrep-rapbles/pdf /wheelnonmoto-eng.pdf

47. Thakore S, Tram J, Hagel BE, Kyle T, Senger $\mathrm{T}$, Belanger $\mathrm{F}$. Injuries among wheeled shoe users: a comparison with other nonmotorized wheeled activities. Paediatr Child Health. 2009;14(8):509-13.
48. CHIRPP injury reports: injuries associated with backyard trampolines: 1999-2003 (full) and 2004-2006 update (limited), all ages [Internet]. Ottawa (ON): Public Health Agency of Canada; [cited 2012 Feb 19]. Available from: http://www.phac-aspc .gc.ca/injury-bles/chirpp/injrep-rapbles/pdf /trampolines-eng.pdf

49. Black GB, Amadeo R. Orthopedic injuries associated with backyard trampoline use in children. Can J Surg. 2003 Jun;46(3):199201.

50. CHIRPP injury reports: injuries associated with unpowered scooters: CHIRPP database as of May 2001: all ages, June 2001 (305 records) [Internet]. Ottawa (ON): Public Health Agency of Canada; [updated 2001 Sep 7; cited 2012 Feb 19]. Available from: http://www.phac-aspc.gc.ca/injury-bles /chirpp/injrep-rapbles/scoot-eng.php

51. Canadian Hospitals Injury Reporting and Prevention Program. CHIRPP injury brief: unintentional drowning and near-drowning, 1990-2003, ages 0-14 years [Internet]. Ottawa (ON): Public Health Agency of Canada; [cited 2012 Feb 19]. Available from: http://www.phac-aspc.gc.ca/injury -bles/chirpp/pdf/CHIRPP_INJURY_BRIEF _DROWN.pdf

52. Canadian Hospitals Injury Reporting and Prevention Program. CHIRPP injury brief: pool, wading pool and hot tub-related body part entrapments, 1990-2003, all ages [Internet]. Ottawa (ON): Public Health Agency of Canada; [cited 2012 Feb 19]. Available from: http://www.phac-aspc .gc.ca/injury-bles/chirpp/pdf/CHIRPP_INJURY _BRIEF_POOL_ENTRAP.pdf

53. Canadian Hospitals Injury Reporting and Prevention Program. CHIRPP injury brief: injuries associated with fireworks, firecrackers and sparklers: cumulative from June 1998 to March 2004 [Internet]. Ottawa (ON): Public Health Agency of Canada; [cited 2012 Feb 19]. Available from: http://www.phac -aspc.gc.ca/injury-bles/chirpp/pdf/CHIRPP \%20INJURY\%20BRIEF-FIREWORKS.pdf

54. CHIRPP injury reports: injuries associated with inline skating: CHIRPP database, summary data for 1998, all ages [Internet]. Ottawa (ON): Public Health Agency of Canada; [cited 2012 Feb 19]. Available from: http://www.phac-aspc.gc.ca/injury-bles /chirpp/injrep-rapbles/inline-eng.php 
55. Canadian Hospitals Injury Reporting and Prevention Program. CHIRPP injury brief: injuries associated with bicycles 2006, ages 1 year and older [Internet]. Ottawa $(\mathrm{ON})$ : Public Health Agency of Canada; [cited 2012 Feb 19]. Available from: http:// www.phac-aspc.gc.ca/injury-bles/chirpp/ pdf/chirpp-bikes-nov2008-eng.pdf

56. Rowe BH, Rowe AM, Bota GW. Bicyclist and environmental factors associated with fatal bicycle-related trauma in Ontario. CMAJ. 1995;152(1):45-53.

57. Yanchar NL, Kennedy R, Russell C. ATVs: motorized toys or vehicles for children? Inj Prev. 2006 Feb;12(1):30-4.

58. Canadian Hospitals Injury Reporting and Prevention Program. CHIRPP injury brief: go-cart related injuries: CHIRPP, 20002002, 5 years and older [Internet]. Ottawa (ON): Public Health Agency of Canada; [cited 2012 Feb 19]. Available from: http:// www.phac-aspc.gc.ca/injury-bles/chirpp /injrep-rapbles/pdf/gc-gk-eng.pdf

59. Injury and Child Maltreatment Section, Health Surveillance and Epidemiology Division. Emergency department surveillance injuries associated with motorized recreational off-highway vehicles: The Canadian Hospitals Injury Reporting and Prevention Program (CHIRPP), all ages, 1990-2007 [Internet]. Ottawa (ON): Public Health Agency of Canada; [cited 2012 Feb 19]. Available from: http://www.phac -aspc.gc.ca/injury-bles/chirpp/injrep-rapbles /pdf/highway-eng.pdf

60. Canadian Hospitals Injury Reporting and Prevention Program. CHIRPP injury brief: injuries associated with powered scooters: CHIRPP, 1998-2005, ages 7 years and older [Internet]. Ottawa (ON): Public Health Agency of Canada; [cited 2012 Feb 19]. Available from: http://www.phac-aspc .gc.ca/injury-bles/chirpp/pdf/CHIRPP_INJURY _BRIEF_POWERED_SCOOTER.pdf

61. Canadian Hospitals Injury Reporting and Prevention Program. CHIRPP injury brief: injuries associated with ice and snow sports and activities 2000-2002, ages 5 years and older [Internet]. Ottawa (ON): Public Health Agency of Canada; [cited 2012 Feb 19]. Available from: http://www.phac -aspc.gc.ca/injury-bles/chirpp/injrep-rapbles /pdf/is-gn-eng.pdf
62. Canadian Hospitals Injury Reporting and Prevention Program. CHIRPP injury brief: injuries associated with sledding, winter 2001-2002 [Internet]. Ottawa (ON): Public Health Agency of Canada; [updated 2009 Apr 22; cited 2012 Feb19]. Available from: http://www.phac-aspc.gc.ca/injury-bles /chirpp/injrep-rapbles/pdf/sledding-glissade01 -02-eng.pdf

63. Voaklander DC, Kelly KD, Sukrani N, Sher A, Rowe BH. Sledding injuries in patients presenting to the emergency department in a northern city. Acad Emerg Med. 2001 Jun;8(6):629-35.

64. Wynne AD, Bota GW, Rowe BH. Sledding trauma in a northeastern Ontario community. J Trauma. 1994;37(5):820-5.

65. CHIRPP - Canadian Hospitals Injury Reporting and Prevention Program: data sampler: injuries associated with snow sports [Internet]. Ottawa (ON): Public Health Agency of Canada; [cited 2012 Feb 19]. Available from: http://www.phac-aspc .gc.ca/injury-bles/chirpp/injrep-rapbles/pdf /snow-sport_sports-neige07_e.pdf

66. Canadian Hospitals Injury Reporting and Prevention Program. CHIRPP injury brief: injuries associated with matches 19932003, Ages 15 years of age and under [Internet]. Ottawa (ON): Public Health Agency of Canada; [updated 2008 Dec 8; cited 2012 Feb 19]. Available from: http:// www.phac-aspc.gc.ca/injury-bles/chirpp /chirpp-matches-nov2008-eng.php

67. CHIRPP - Canadian Hospitals Injury Reporting and Prevention Program: data sampler: injuries associated with all-terrain vehicles (ATVs): CHIRPP database, 19992001, all ages -895 records. [Internet]. Ottawa (ON): Public Health Agency of Canada; [cited 2012 Feb 19]. Available from: http://www.phac-aspc.gc.ca/injury -bles/chirpp/injrep-rapbles/pdf/atv_e.pdf

68. Alawi K, Lynch T, Lim R. All-terrain vehicle major injury patterns in children: a fiveyear review in Southwestern Ontario. CJEM. 2006 Jul;8(4):277-80.

69. Lim GW, Belton KL, Pickett W, Schopflocher DP, Voaklander DC. Fatal and non-fatal machine-related injuries suffered by children in Alberta, Canada, 1990-1997. Am J Ind Med. 2004 Feb;45(2): 177-85.
70. Murphy N, Yanchar NL. Yet more pediatric injuries associated with all-terrain vehicles: should kids be using them? J Trauma. 2004;56(6):1185-90.

71. Sibley AK, Tallon JM. Major injury associated with all-terrain vehicle use in Nova Scotia: a 5-year review. CJEM. 2002;4(4): 263-7.

72. Su W, Hui T, Shaw K. All-terrain vehicle injury patterns: are current regulations effective? J Pediatr Surg. 2006;41(5):931-4.

73. Macnab AJ, Cadman R. Demographics of alpine skiing and snowboarding injury: lessons for prevention programs. Inj Prev. 1996 Dec;2(4):286-9.

74. Injury and Child Maltreatment Section, Health Surveillance and Epidemiology Division. Emergency department surveillance injuries associated with water tubing and water skiing: The Canadian Hospitals Injury Reporting and Prevention Program (CHIRPP), all ages, 1990-2008 [Internet]. Ottawa (ON): Public Health Agency of Canada; [cited 2012 Feb 19]. Available from: http://www.phac-aspc.gc.ca/injury -bles/chirpp/pdf/wtski-eng.pdf

75. Canadian Hospitals Injury Reporting and Prevention Program. CHIRPP injury brief: injuries associated with lawnmowers, 19902006, all ages [Internet]. Ottawa (ON): Public Health Agency of Canada; [cited 2012 Feb 19]. Available from: http://www.phac -aspc.gc.ca/injury-bles/chirpp/pdf/CHIRPP _INJURY_BRIEF_LAWNMOWERS.pdf

76. CHIRPP injury reports: injuries associated with personal powered watercraft: entire CHIRPP database, as of June 1998, all ages [Internet]. Ottawa (ON): Public Health Agency of Canada; [updated 1999 Jan 11; cited 2012 Feb 19]. Available from: http:// www.phac-aspc.gc.ca/injury-bles/chirpp /injrep-rapbles/jetski-eng.php

77. Stewart RL, Black GB. Snowmobile trauma: 10 years' experience at Manitoba's tertiary trauma centre. Can J Surg. 2004 Apr;47(2): 90-4.

78. Kirby RL, Ackroyd-Stolarz SA, Brown MG, Kirkland SA, MacLeod DA. Wheelchairrelated accidents caused by tips and falls among noninstitutionalized users of manually propelled wheelchairs in Nova Scotia. Am J Phys Med Rehabil. 1994;73(5):319-30. 
79. Sherman GJ. Trampoline-related injuries in the Children's Hospitals Injury, Research and Prevention Program. Chronic Dis Can. 1991;12(5):78-80.

80. Hagel BE, Russell K, Goulet C, NettelAguirre A, Pless IB. Helmet use and risk of neck injury in skiers and snowboarders. Am J Epidemiol. 2010 May 15;171(10): 1134-43. 